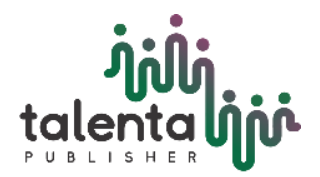

\title{
Karakteristik Zat Warna Antosianin (Adenanthera pavonina L) dari Kulit Biji Saga sebagai Pewarna Alami Menggunakan Metode Sokletasi
}

\section{Characteristics of Anthocyanin (Adenanthera pavonina L) from Saga Seeds as Natural Dyes Used Soxhletation Method}

\author{
Halimatuddahliana*, Setiaty Pandia, Fira Ayu Hasmita \\ Departemen Teknik Kimia, Fakultas Teknik, Universitas Sumatera Utara \\ Jalan Almamater Kampus USU, Medan, 20155, Indonesia \\ *Email: h_dahliana@yahoo.com
}

\begin{abstract}
Abstrak
Pada umumnya zat warna yang digunakan dalam kehidupan sehari-hari menggunakan pewarna sintetis. Salah satu bahan yang dapat digunakan untuk zat warna alami adalah dari kulit biji saga (Adenanthera pavonina L). Saga (Adenanthera pavonina L.) merupakan pohon yang memiliki biji kecil berwarna merah berpotensi sebagai salah satu sumber antosianin yang dapat berfungsi sebagai pewarna alami, antioksidan dan antikarsinogen. Penelitian ini bertujuan untuk mengetahui jenis pelarut dan waktu ekstraksi yang terbaik digunakan untuk ekstraksi antosianin dari kulit biji saga. Ekstraksi senyawa antosianin dari kulit biji saga dilakukan dengan metode sokletasi. Adapun variabel pada penelitian ini adalah jenis pelarut (aquadest-asam sitrat $5 \%$ dan etanolasam sitrat $5 \%(\mathrm{~b} / \mathrm{v}))$ dan waktu ekstraksi (30, 60, 120 menit). Parameter yang digunakan yaitu analisis kualitatif dan kuantitatif (rendemen ekstrak, total konsentrasi antosianin, aktivitas antioksidan, intensitas warna dan konsentrasi letal toksisitas antosianin pada ekstrak). Hasil penelitian menunjukkan bahwa ektraksi dari kulit biji saga memiliki kandungan antosianin dengan karakteristik terbaik pada perlakuan pelarut aquadest-asam sitrat 5 $\%$ rendemen ekstrak dengan waktu ekstraksi 120 menit 64,488\% (b/b), total antosianin dengan waktu ekstraksi 120 menit 100,026 (mg/L), intensitas warna dengan waktu ekstraksi 60 menit 0,528, aktivitas antioksidan dengan waktu ekstraksi 60 menit (IC 50$)$ 11,622 ppm dan aktivitas toksisitas 63,326 ppm.
\end{abstract}

Kata kunci : antosianin, sokletasi, kulit biji saga, pewarna alami

\begin{abstract}
In general, dyes that are used in daily life using synthetic dyes. One material that can be used for natural pigment are from saga seeds (Adenanthera pavonina $L$ ). Saga (Adenanthera pavonina $L$ ) is a tree that has small red seeds which is one source of anthocyanin which can be used as natural dyes, antioxidants and anticarcinogens. In this research aims to find the type of solvent and the best extraction time used for the extraction of anthocyanin from saga seeds. Extraction of anthocyanin from saga seeds used soxhletation method. The variables this research there are the type of solvent $(5 \%$ citric acid $5 \%$ and citric acid $5 \%(w / v))$ and the extraction time $(30$, 60, 120 minutes). The parameters used are qualitative and quantitative analysis (total yield, total anthocyanin concentration, antioxidant activity, intensity colour and lethal concentration of anthocyanin toxicity in extracts). The result observationaling show that the extraction from saga seeds that have best characteristics in aquadestcitric acid 5\% solvent extract yield with extraction time 120 minutes $64.448 \%(w / w)$, total anthocyanin with extractions time 120 minutes $100.026(\mathrm{mg} / \mathrm{L})$, color intensity with extraction time 60 minutes 0.528 , antioxidant activity $\left(I_{50}\right) 11.622$ ppm and toxicity activity with extraction time 60 minutes 63.326 ppm.
\end{abstract}

Keywords: anthocyanin, soxhletation, saga seeds, natutal dyes

\section{Pendahuluan}

Pewarna telah lama digunakan pada bahan makanan dan minuman untuk memperbaiki tampilan produk pangan. Pada mulanya zat warna yang digunakan adalah zat warna alami dari tumbuhan dan hewan. Semakin berkembangnya ilmu dan teknologi saat ini, penggunaan zat warna alami semakin berkurang dalam industri pangan yang digantikan oleh zat warna sintetik. Hal ini disebabkan bahan-bahan pewarna sintetik lebih murah dan memberikan warna yang lebih stabil dibandingkan pewarna alami [1].
Penggunaan dari pewarna sintetik menyebabkan gangguan kesehatan dan tidak stabilnyakeseimbangan lingkungan. Pewarna alami adalah salah satu pilihan yang menjanjikan untuk mengembangkan pewarna tekstil yang prosesnya lebih hijau dan alasan tersebut tercermin pada peningkatan jumlah publikasi terbaru [2].

Pewarna sintetik ini biasanya bersifat karsinogenik dan berbahaya bagi lingkungan. Limbah yang dihasilkan dari proses produksi industri tekstil juga mengandung logam berat seperti kromium $(\mathrm{Cr})$, 
timah ( $\mathrm{Sn})$, tembaga $(\mathrm{Cu})$, dan seng $(\mathrm{Zn})$ karena dampak negatif terhadap lingkungan dan kesehatan manusia, kepedulian penggunaan kembali pewarna alam harus didorong [3].

Pewarna alami memiliki biodegrabilitas yang lebih baik dan umumnya memiliki kompatibilitas tinggi dengan lingkungan. Selain itu, tidak beracun, non-alergi pada kulit, non-karsinogenik, mudah tersedia dan terbarukan [4]. Oleh karena itu, perlu dicari sumber-sumber pewarna alami yang dapat digunakan dalam pengolahan pangan sehingga dihasilkan pewarna yang aman dengan harga relatif murah.Salah satu contoh pewarna alami yang bisa digunakan adalah antosianin.

Pada penelitian ini, kulit biji saga akan diteliti sebagai sumber antosianin. Kondisi yang optimal akan dikaji untuk mengekstraksi antosianin dari kulit biji saga dengan menggunakan metode sokletasi. Penelitian ini memvariasikankondisi operasi yaitu jenis pelarut dan waktu ekstraksi.

\section{Teori}

Saga (Adenanthera pavonina L.) merupakan pohon yang memiliki biji kecil berwarna merah dengan batang pohon yang tinggi, dan daun yang lebih kecil [5]. Habitat dan penyebaran alaminya di Srilangka, Selatan Myanmar, Indo-China, Selatan China, Thailand, Malaysia, Kepulauan Solomon dan Utara Australia [6]. Biji saga berukuran hampir sama dengan kedelai, berbentuk bulat gepeng, kulit bijinya berwarna merah dan keras. Daun, kulit batang, dan akar dari tanaman ini dapat dimanfaatkan sebagai obat asma, inflamasi, bisul, rematik, tumor, diarrhoea dan tonik. [7].

Menurut Penelitian Abu et al., (2012) mengatakan bahwa kandungan dari biji saga yaitu alkaloid, minyak, steroid, lektin, flavanoid, dan antosianin [8]. Alkaloid pada biji meliputi abrin, hipaforin, kholin, dan precatorin.Penelitian oleh Partha et al., (2015) mengatakan bahwa kulit biji saga (Adenanthera pavonina $L$ ) dengan melakukan shinoda test dengan menggunakan pelarut metanol bahwa positif terdapat kandungan flavonoid [9].

Antosinin adalah pigmen yang larut dalam air, yang tersebar luas di buah dan sayur-sayuran dan bertanggung jawab terhadap warna merah, ungu dan biru pada bunga serta biji tanaman. Tidak kurang dari 500 jantosianin di alam, dan hanya enam struktur umum, yaitu cyanidin, peonidin, pelargonidin, petunidin, delphinidin dan malvidin, yang dimiliki sejauh penemuan ini [10].

Antosianin adalah suatu kelas dari senyawa flavonoid, yang secara luas terbagi dalam polifenol tumbuhan. Flavonol, flavan-3-ol, flavon, flavanon, dan flavanonol adalah kelas tambahan flavonoid yang berbeda dalam oksidasi dari antosianin. Larutan pada senyawa flavonoid adalah tak berwarna atau kuning pucat [11]. Senyawa golongan flavonoid termasuk senyawa polar dan dapat diekstraksi dengan pelarut yang bersifat polar pula. Beberapa pelarut yang bersifat polar diantaranya etanol, air dan etil asetat. Kondisi asam akan mempengaruhi hasil ekstraksi [12].

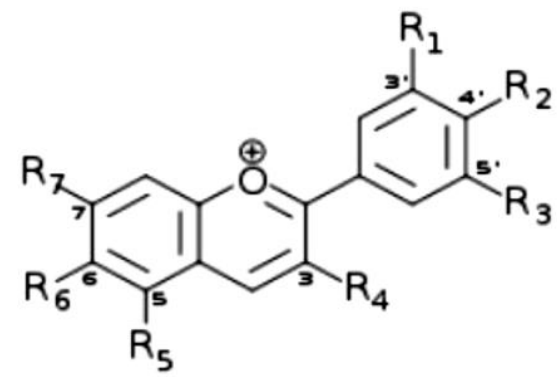

Gambar 1. Struktur antosianin [13]

Antosianin adalah komponen bioaktif kelompok flavonoid yang dapat memberikan warna merah, ungu, biru, pada bunga, daun, umbi, buah dan sayur.Antosianin larut dalam air dan aman untuk dikonsumsi sehingga, umumnya digunakan sebagai pewarna alami untuk produk makanan dan minuman [13].

Senyawa antosianin berfungsi sebagai antioksidan dan penangkap radikal bebas, sehingga berperan untuk mencegah terjadi penuaan, kanker, dan penyakit degeneratif. Selain itu, antosianin juga memiliki kemampuan sebagai antimutagenik dan antikarsinogenik, mencegah gangguan fungsi hati, antihipertensi, dan menurunkan kadar gula darah [14].

\section{Metodologi Penelitian}

Pada penelitian ini bahan yang digunakan antara lain kulit biji saga (Adenanthera pavonina $L$ ), etanol $\left(\mathrm{C}_{2} \mathrm{H}_{5} \mathrm{OH}\right)$, asam sitrat $\left(\mathrm{C}_{6} \mathrm{H}_{8} \mathrm{O}_{7}\right)$, aquadest $\left(\mathrm{H}_{2} \mathrm{O}\right)$, DPPH (1,1-diphenyl-2-picrylhydrazil), methanol $\left(\mathrm{CH}_{3} \mathrm{OH}\right)$, larutan buffer $\mathrm{KCl}$ dan larutan buffer $\mathrm{Na}$-asetat .

Adapun alat-alat yang digunakan heating mantle, soklet, refluks, neraca analitik, aerator, blender, kertas saring, beaker glass, erlenmeyer, corong gelas, gelas ukur, tabung reaksi, kuvet, rotary evaporator RE-100 Pro Scilogex, spektrofotometer shimadzu UV 1800.

\section{Prosedur Penelitian}

Penelitian ini dilakukan dalam tiga tahap yaitu pretreatment bahan baku, proses ekstraksi dengan metode soklet, proses pemekatan ekstrak dengan rotary vacuum evaporatorr RE-100 Pro Scilogex dan analisis karakterisasi ektrak kulit biji saga. Proses ekstraksi dilakukan dengan dua tahap yaitu ekstraksi pigmen antosianin dengan variasi waktu ekstraksi 30, 60 dan 120 menit dan rasio bahan : pelarut yaitu 1:7 (b/v) menggunakan pelarut etanol 96\% dan aquadest yang ditambahkan asam sitrat 5\% dimana suhu ektraksi berlangsung pada kondisi sesuai titik didih pelarut yaitu $70^{\circ} \mathrm{C}$ pada pelarut etanol dan $100^{\circ} \mathrm{C}$ pelarut aquadest. Kemudian ekstraksi untuk uji 
toksisitas untuk mengetahui kandungan toksik yang terdapat pada bahan yaitu sebanyak 50 gram kulit biji saga diesktraksi dengan $500 \mathrm{ml}$ masing-masing pelarut pada suhu titik didih masing-masing pelarut sampai ekstrak mencapai titik maksimum. Setelah didapat ekstrak berupa filtrat bebas ampas kemudian dipekatkan dengan rotary vacuum evaporatorr RE100 Pro Scilogex suhu $50^{\circ} \mathrm{C}$ dan kecepatan pemutaran $80 \mathrm{rpm}$ hingga didapat konsentrat pekat. Kemudian pada hasil ekstrak tersebut dilakukan analisis karakterisasi berupa analisa kualitatif, analisa rendemen ekstrak, analisa konsentrasi total antosianin, analisa intensitas zat warna, analisa aktivitas antioksidan dan analisa aktivitas toksisitas.

\section{Hasil}

\section{Uji Pembuktian Antosianin Secara Kualitatif}

Uji pembuktian antosianin secara kualitatif merupakan uji pendahuluan yang dilakukan untuk mengidentifikasi kandungan senyawa aktif yang terdapat di dalam sampel. Uji kualitatif antosianin dari ekstraksi kulit biji saga dilakukan dengan menggunakan pelarut $\mathrm{HCl}$ dan $\mathrm{NaOH}$. Hasil uji pembuktian antosianin dapat dilihat pada tabel 1 .

Tabel 1. Data Uji Pembuktian Antosianin

\begin{tabular}{|c|c|c|c|c|}
\hline $\begin{array}{c}\text { Jenis } \\
\text { Pelarut }\end{array}$ & Senyawa & Reaksi & Perubahan Warna & Hasil \\
\hline \multirow{2}{*}{ Etanol } & \multirow{4}{*}{ Antosianin } & $\begin{array}{l}\text { Esktrak }+\mathrm{HCl} 2 \mathrm{M}+ \\
\text { pemanasan } 5 \text { menit }\end{array}$ & $\begin{array}{l}\text { Merah mudah menjadi } \\
\text { merah terang }\end{array}$ & Positif \\
\hline & & Esktrak + NaOH $2 \mathrm{M}$ & $\begin{array}{l}\text { Merah terang menjadi } \\
\text { coklat kehitaman }\end{array}$ & Positif \\
\hline \multirow{2}{*}{ Aquadest } & & $\begin{array}{l}\text { Esktrak }+\mathrm{HCl} 2 \mathrm{M}+ \\
\text { pemanasan } 5 \text { menit }\end{array}$ & $\begin{array}{l}\text { Merah mudah menjadi } \\
\text { merah terang }\end{array}$ & Positif \\
\hline & & Esktrak + NaOH $2 \mathrm{M}$ & $\begin{array}{l}\text { Merah terang menjadi } \\
\text { coklat kehitaman }\end{array}$ & Positif \\
\hline
\end{tabular}

Berdasarkan Tabel 1. ekstrak etanol dan aquadest kulit biji saga dengan menggunakan $\mathrm{HCl}$ terjadi perubahan warna dari merah muda menjadi merah terang yang menunjukkan hasil positif bahwa antosianin pada kondisi asam memiliki gugus metoksi yang dominan menyebabkan warna merah dan relatif lebih stabil. Pada penambahan $\mathrm{NaOH}$ terjadi perubahan warna dari merah terang menjadi coklat kehitaman yang menunjukkan hasil positif bahwa antosianin pada kondisi basa menjadi berwarna gelap karena adanya gugus hidroksi yang dominan menyebabkan warna cenderung relatif tidak stabil. Hasil penelitian analisa kualitatif yang diperoleh juga tidak jauh berbeda dengan hasil penelitian yang dilakukan Fauziah, dkk., 2016 melalui uji fitokimia [15]

\section{Pengaruh Waktu Ekstraksi dan Jenis Pelarut Berdasarkan Rendemen Ekstrak}

Rendemen ekstrak antosianin menunjukkan persen perolehan antosianin dari kulit biji saga. Rendemen dilakukan dengan cara berat hasil dibagi dengan berat awal. Setelah proses penyaringan, ekstrak kulit biji saga dimasukkan ke dalam alat rotary vacum evaporator hal ini bertujuan untuk menguapkan pelarut dengan suhu dibawah titik didih pelarut dengan menaikkan tekanan karena antosianin dapat rusak pada suhu $60^{\circ} \mathrm{C}$. Ekstrak tersebut dirotary hingga kering hingga diperoleh konsentrat pekat kemudian rendemen dapat dihitung dengan rumus yang tertera pada lampiran. Pengaruh waktu ektraksi dan jenis pelarut terhadap rendemen ekstrak ditunjukkan pada gambar 3 sebagai berikut:



Gambar 2. Pengaruh Waktu Ekstraksi dan Jenis Pelarut Terhadap Persen Rendemen Ekstrak Antosianin

Pada Gambar 2. dapat dilihat bahwa rendemen ekstrak yang dihasilkan cenderung meningkat dengan peningkatan waktu ekstraksi. Semakin lama waktu ekstraksi, rendemen yang diperoleh pun akan meningkat, hal tersebut dikarenakan semakin banyak senyawa yang terlarut ke dalam pelarut [16]. Semakin lama waktu ekstraksi yang digunakan, waktu kontak antara sampel dan pelarut semakin lama sehingga jumlah senyawa yang terekstraksi semakin banyak. Kondisi ini akan terus berlanjut hingga tercapai kondisi kesetimbangan antara konsentrasi senyawa di dalam bahan baku dengan konsentrasi senyawa di pelarut [17]. Dari gambar 3, rendemen ekstrak kulit biji saga yang dihasilkan berbanding lurus dengan semakin lamanya waktu ekstraksi. 
Hasil yang diperoleh memperlihatkan bahwa untuk jenis pelarut pada pelarut etanol dengan waktu ekstraksi selama 120 menit 55,692\% menghasilkan rendemen ekstrak yang lebih banyak dibandingkan waktu 60 menit $51,592 \%$ dan 30 menit $36,424 \%$. Sedangkan pada pelarut aquadest dengan waktu ekstraksi selama 120 menit 68,488\% menghasilkan rendemen ekstrak yang lebih banyak dibandingkan waktu 60 menit 50,856\% dan 30 menit 51,028\%. Dari data yang diperoleh dapat diambil kesimpulan bahwa nilai rendemen ekstrak pada pelarut aquadest lebih tinggi dibandingan dengan pelarut etanol hal ini disebabkan aquadest merupakan pelarut yang lebih polar daripada etanol dalam mengekstraksi antosianin serta semakin lama waktu ekstraksi, rendemen yang diperoleh juga akan semakin banyak.

\section{Pengaruh Waktu Ekstraksi dan Jenis Pelarut Berdasarkan Analisis Kadar Total Antosianin}

Uji kuantitatif kadar antosianin dilakukan dengan metode differential $\mathrm{pH}$ yaitu $\mathrm{pH} 1$ dan $\mathrm{pH} 4,5$ dan diukur absorbansinya dengan spektrofotometer shimadzu UV 1800 pada panjang gelombang $510 \mathrm{~nm}$ dan panjang gelombang $700 \mathrm{~nm}$. Pengaruh waktu ekstraksi dan pelarut terhadap kadar total antosianin ditunjukkan pada gambar 3 sebagai berikut:

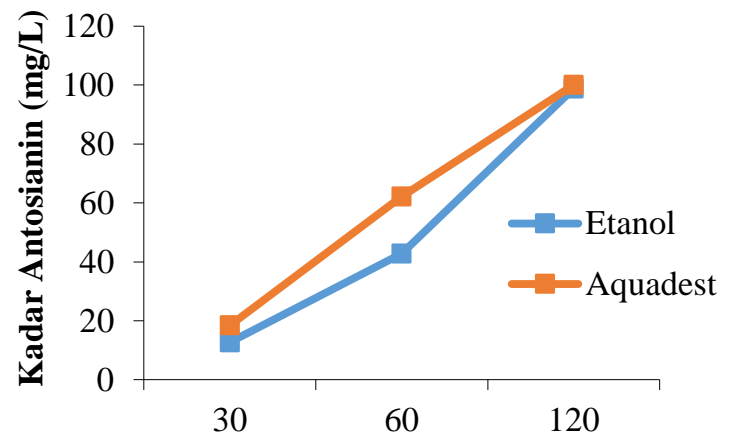

Waktu Ekstraksi (menit)

Gambar 3. Pengaruh Waktu Ekstraksi dan Jenis Pelarut Terhadap Kadar Total Antosianin

Pada Gambar 3. dapat dilihat bahwa kadar total antosianin yang dihasilkan cenderung meningkat dengan peningkatan waktu ekstraksi. Hal ini disebabkan karena semakin lama waktu ekstraksi maka kontak antar bahan dan pelarut semakin lama sehingga semakin banyak antosianin yang terlarut didalamnya [18].

Hasil yang diperoleh memperlihatkan bahwa untuk variasi jenis pelarut pada etanol dengan waktu ekstraksi selama 120 menit 98,857 (mg/L) menghasilkan antosianin dengan kadar lebih tinggi dibandingkan waktu 60 menit 42,749 (mg/L) dan 30 menit 12,691 (mg/L). Sedangkan pada pelarut aquadest dengan waktu ekstraksi selama 120 menit 100,026 (mg/L) menghasilkan antosianin dengan kadar lebih tinggi dibandingkan waktu 60 menit $62,120(\mathrm{mg} / \mathrm{L})$ dan 30 menit 18,369 (mg/L).

\section{Pengaruh Waktu Ekstraksi dan Jenis Pelarut Berdasarkan Analisis Intensitas Warna}

Intensitas warna menunjukkan kepekatan warna merah dalam kulit biji saga. Penentuan intensitas warna dari ekstrak kulit biji saga ditentukan dalam panjang gelombang maksimum $515 \mathrm{~nm}$. Pengaruh waktu ekstraksi dan pelarut terhadap intensitas warna antosianin ditunjukkan pada gambar 4 sebagai berikut:

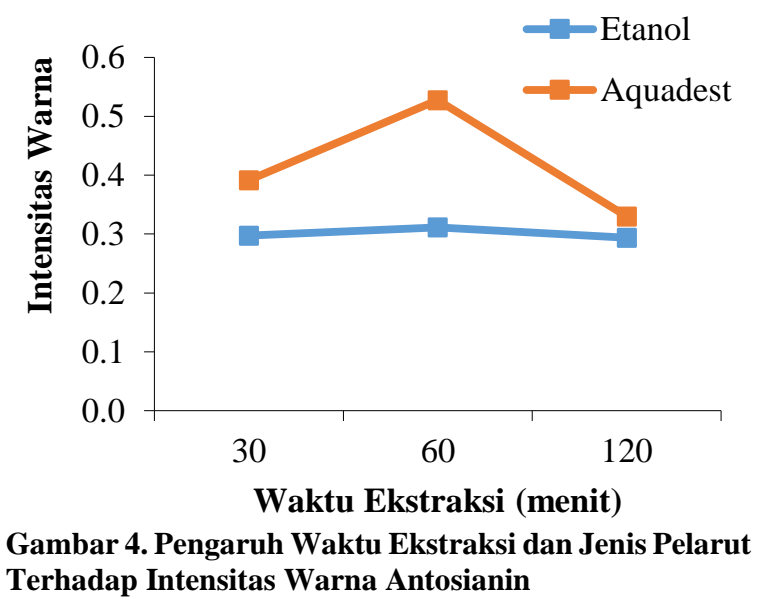

Pada Gambar 4. dapat dilihat bahwa intensitas warna antosianin yang dihasilkan mengalami kenaikan dan penurunan seiring dengan peningkatan waktu ekstraksi. Hal ini disebabkan karena waktu ekstraksi pigmen antosianin berpengaruh terhadap kadar antosianin maupun kestabilan warna pigmen. Semakin lama waktu ekstraksi maka terjadinya kontak antara pelarut dengan bahan akan semakin lama.

Hasil yang diperoleh memperlihatkan bahwa pada ekstraksi selama 30 menit nilai intensitas zat warna untuk jenis pelarut etanol dan aquadest $(0,298$ dan 0,391). Kemudian pada waktu ekstraksi selama 1 jam memberikan nilai intensitas warna tertinggi yaitu 0,311 pada pelarut etanol dan 0,528 pada pelarut aquadest. Hal ini dikarenakan ekstraksi

selama 1 jam memberikan waktu yang cukup untuk menembus dinding sel dan menarik keluar senyawasenyawa yang terkandung dalam bahan, sehingga dihasilkan nilai intensitas warna yang paling tinggi. Namun pada waktu ekstraksi 2 jam nilai intensitas warna mengalami penurunan yaitu untuk jenis pelarut etanol dan aquadest $(0,294$ dan 0,330) hal ini disebabkan, semakin lama waktu ekstraksi pigmen antosianin mengalami degradasi (dekomposisi) antosianin dan perubahan struktur pigmen sehingga terjadi pemucatan dari bentuk aglikon menjadi kalkon (tidak berwarna) [19].

Dari data yang diperoleh dapat diambil kesimpulan bahwa waktu ekstraksi selama 1 jam merupakan waktu relatif baik untuk memperoleh banyaknya pigmen warna antosianin. 


\section{Pengaruh Waktu Ekstraksi dan Jenis Pelarut Berdasarkan Analisa Aktivitas Antioksidan}

Pengujian aktivitas antikosidan ekstrak kulit biji saga dalam penelitian ini dilakukan menggunakan metode DPPH. Pada penentuan aktivitas antioksidan ekstrak kulit biji saga terlebih dahulu dilakukan pengukuran panjang gelombang maksimum menggunakan larutan standar. Panjang gelombang maksimum yang diperoleh sebesar $517 \mathrm{~nm}$. Panjang gelombang yang diperoleh tersebut digunakan untuk mengukur aktivitas antioksidan sampel.

Menurut Molyneux (2004), senyawa yang memiliki sifat sebagai antioksidan yang sangat kuat apabila $\mathrm{IC}_{50}$ antara 50-100 ppm, aktivitas sedang apabila nilai $\mathrm{IC}_{50}$ antara $100-150 \mathrm{ppm}$ dan bersifat lemah apabila nilai antara 150-200 ppm [20]. Untuk melihat pengaruh waktu ekstraksi dan pelarut terhadap nilai $\mathrm{IC}_{50}$ ditunjukkan pada gambar 5 sebagai berikut:



Waktu Ekstraksi (menit)

Gambar 5. Grafik Pengaruh Waktu Ekstraksi dan Jenis Pelarut Terhadap Nilai IC $_{50}(\mathrm{ppm})$

Pada Gambar 5. dapat dilihat bahwa nilai $\mathrm{IC}_{50}$ (konsentrasi efektif ekstrak) pada jenis pelarut etanol cenderung meningkat seiring dengan peningkatan waktu ekstraksi. Hal tersebut disebabkan waktu kontak antara sampel dan pelarut semakin lama sehingga jumlah senyawa yang terekstraksi semakin banyak dan kemampuan antioksidan untuk menangkap radikal bebas semakin besar [17]. Pada waktu ekstraksi selama 2 jam menunjukkan nilai $\mathrm{IC}_{50}$ tertinggi yaitu 15,109 yaitu antioksidan yang sangat kuat (nilai $\mathrm{IC}_{50}<50$ ).

Sedangkan pada jenis pelarut aquadest nilai $\mathrm{IC}_{50}$ mengalami kenaikan dan penurunan seiring dengan peningkatan waktu ekstraksi. Hal ini terjadi akibat kerusakan antioksidan didalam ekstrak yang dipengaruhi oleh lamanya waktu kontak antara zat aktif dengan pelarut yang suhunya semakin meningkat akibat pemanasan yang lama [21]. Pada waktu ekstraksi selama 1 jam memberikan waktu yang cukup untuk menembus dinding sel dan menarik keluar senyawa-senyawa yang terkandung dalam bahan, sehingga dihasilkan nilai $\mathrm{IC}_{50}$ tertinggi yaitu 11,622 yaitu antioksidan yang sangat kuat (nilai $\mathrm{IC}_{50}<50$ ).

\section{Pengaruh Jenis Pelarut Terhadap Analisis Aktivitas Toksisitas}

Ekstrak kulit biji saga terhadap jenis pelarut etanol dan aquadest yang diuji dengan menggunakan metode Brine Shrimp Lethality Test (BSLT) yang mampu mendeteksi tingkat toksisitas sebagai tahap awal pengujian aktivitas. Ekstrak setiap fraksi diuji dengan menggunakan larva artemia jumlah kematian larva dihitung dengan menggunakan analisa probit. Nilai LC $_{50}$ (Letal Consentration) adalah jumlah kadar yang menyebabkan kematian dari 50\% hewan uji dalam selang beberapa waktu tertentu.

Berdasarkan nilai toksisitas dalam senyawa dari tumbuhan jika $\mathrm{LC}_{50} \leq 30 \mathrm{ppm}$ maka bersifat sangat toksik, ketika konsentrasi ekstrak $31 \mathrm{ppm} \leq$ $\mathrm{LC}_{50} \leq 1000$ ppm bersifat toksik jika $\mathrm{LC}_{50}>1000 \mathrm{ppm}$ maka bersifat tidak toksik [10]. Pada hasil uji menunjukkan bahwa ekstrak aquadest kulit biji saga mempunyai aktivitas toksisitas yang paling kuat dengan nilai $\mathrm{LC}_{50}$ sebesar 63,326 ppm sedangkan ekstrak etanol dengan nilai $\mathrm{LC}_{50}$ sebesar 334,643 ppm. Tingkat toksisitas tersebut juga dapat menunjukkan potensi aktivitasnya sebagai antikanker dimana semakin kecil nilai $\mathrm{LC}_{50}$ maka semakin toksik suatu senyawa dan berpotensi sebagai antikanker [22].

Tingkat kematian larva tidak hanya dipengaruhi oleh komponen kimia yang terkandung di dalamnya tetapi erat hubungannnya dengan konsentrasi terhadap larva artemia. Untuk melihat pengaruh tingkat presentasi kematian artemia salina leach terhadap konsentrasi ditunjukkan pada gambar 6 sebagai berikut:

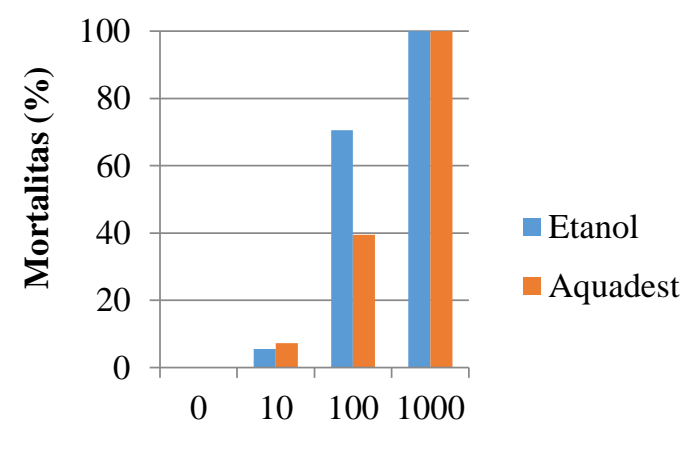

Konsentrasi (ppm)

Gambar 6. Grafik Pengaruh Persentase Kematian Artemia Salina Leach Terhadap Konsentrasi

Pada Gambar 6. dapat dilihat bahwa laju mortalitas larva meningkat dengan meningkatnya konsentrasi larutan uji dan ekstrak pelarut etanol memiliki tingat persen kematian larva paling tinggi dibandingkan ekstrak pelarut aquadest bahkan dikonsentrasi 100 ppm pada ekstrak pelarut etanol mampu mematikan 70,556\% larva artemia salina leach dalam waktu 24 jam. Tinggi rendahnya persentasi kematian larva berbanding terbalik dengan nilai $\mathrm{LC}_{50}$. Ketika nilai $\mathrm{LC}_{50}$ besar maka tingkat 
kematian larva akan semakin rendah begitu juga sebaliknya.

Berdasarkan Peraturan Kepala Badan Pengawas Obat dan Makanan RI No.37 Tahun 2013 Tentang Batas Maksimum Penggunaan Bahan Tambahan Pewarna, bahwa jumlah maksimum zat antosianin ditambahkan pada bahan pangan yaitu 0 2,5 $\mathrm{mg} / \mathrm{kg}$ berat badan yang dapat dikonsumsi berdasarkan asupan harian yang dapat diterima (Acceptable Daily Intake) yang biasa disingkat ADI. Hal tersebut jika tingkat konsumsi terhadap sampel tersebut secara terus-menerus akan menyebabkan toksisitas atau keracunan bagi tubuh manusia.

Berdasarkan data yang diperoleh dari gambar grafik 4.9 bahwa konsentrasi sampel pada 0 dan 10 ppm persen kematian larva yaitu 0-5,556 \% untuk ekstrak pelarut etanol sedangkan untuk ekstrak pelarut aquadest sebesar 0-7,222 \%. Hal ini sampel dapat dikatakan aman ketika konsentrasi berada diambang sampai $10 \mathrm{ppm}$ sesuai yang ditetapkan oleh peraturan pemerintah yaitu ADI zat antosianin sebesar 0-2,5 $\mathrm{mg} / \mathrm{kg}$.

Ketika konsentrasi sampel sebesar 100 ppm tingkat kematian larva pada ekstrak pelarut etanol mampu mematikan 70,556\% larva artemia salina leach dalam waktu 24 jam. Hal ini disebabkan konsentrasi sampel terlalu tinggi dan pelarut yang digunakan diduga mempunyai aktivitas sitotoksik. Sifat sitotoksik dari ekstrak pada pelarut etanol mengandung flavonoida yang mengandung glikosida sehingga senyawa ini menyumbang aktivitas sitotoksik [23]. Hal ini diikuti dengan pemakaian konsentrasi yang terlalu tinggi sehingga tidak aman bagi pencernaan yang dapat menyebabkan keracunan bagi hewan uji.

\section{Kesimpulan}

Berdasarkan hasil penelitian yang telah dilakukan dapat disimpulkan bahwa kulit biji saga mengandung antosianin dibuktikan dengan hasil identifikasi secara kualitatif. Pelarut yang menghasilkan karakteristik ekstrak kulit biji saga terbaik yaitu pelarut Aquadest dengan waktu ekstraksi 120 menit. Semakin tinggi konsentrasi pada uji toksisitas dapat menyebabkan tingginya kematian pada hewan uji sehingga konsentrasi yang aman untuk makhluk hidup yaitu konsentrasi 0 dan 10 ppm sesuai dengan ketetapan peraturan zat antosianin dapat dikonsumsi pada bahan pangan dengan nilai ADI sebesar $0-2,5 \mathrm{mg} / \mathrm{kg}$.

\section{Daftar Pustaka}

[1] Laura Olivia Siahaan, Elvi Rasida Florentina Hutapea, and Rondang Tambun, "Ekstraksi Pigmen Antosianin Dari Kulit Rambutan (Nephelium Lappaceum) Dengan Pelarut Etanol," 2014.

[2] M. G. Uddin, "Extraction of eco-friendly natural dyes from mango leaves and their application on silk fabric," Textiles and Clothing Sustainability, vol. 1, no. 1, Dec. 2015.

[3] A. W. Indrianingsih, C. Darsih, and R. Maryana, "Pewarna Alam Dari Ekstrak Tanaman Dan Aplikasinya Di Usaha Kecil Menengah Tekstil Indonesia," Seminar Nasional Kimia dan Pendidikan Kimia V, no. April, p. 684, 2013.

[4] H. Hernani, R. Risfaheri, and T. Hidayat, "Ekstraksi Dan Aplikasi Pewarna Alami Kayu Secang Dan Jambal Dengan Beberapa Jenis Pelarut," 2017.

[5] L. Sinaga, "Sifat Antirayap Ekstrak Kulit Biji Saga (Adenanthera pavonina Linn)," 2012.

[6] E. Suita, "Seri Teknologi Perbenihan Tanaman Hutan Saga Pohon (Adenanthera pavonina L.)," Balai Penelitian Teknologi Perbenihan Tanaman Hutan, vol. 13, pp. 1-12, 2013.

[7] K. C. Kumoro, "Potensi Biji Saga Pohon (Adenanthera pavonina, Linn) Sebagai Bahan Baku Tempe; Sensori, Kualitas Gizi, Serat Pangan dan Kapasitas Antioksidan," in Sensori, Kualitas Gizi, Serat Pangan, Dan Kapasitas Antioksidan, 2012, pp. 1-61.

[8] S. M. Abu, H. A. B. M. Manirul, M. A. Majid, and I. M. Anwarul, "Antifertility studies on ethanolic extract of Abrus precatorius L on swiss male albino mice," International Journal of Pharmaceutical Sciences, vol. 3, no. 1, pp. 288-292, 2012.

[9] G. Partha and C. Habibur Rahaman, "Pharmacognostic, phytochemical and antioxidant studies of Adenanthera pavonina L," International Journal of Pharmacognosy and Phytochemical Research, vol. 7, no. 1, pp. 30-37, 2015.

[10] Y. Zhu et al., "Metabolism and prebiotics activity of anthocyanins from black rice (Oryza sativa L.) in vitro," PLoS ONE, vol. 13, no. 4, 2018.

[11] R. E. Wrolstad and D. Ph, "The Possible Health Benefits of Anthocyanin Pigments and Polyphenolics," Oregon State University, 2012.

[12] Lidya Simanjuntak, Chairina Sinaga, and Fatimah, "Ekstraksi Pigmen Antosianin Dari Kulit Buah Naga Merah (Hylocereus polyrhizus)," 2014.

[13] S. R. Paliling, "Karakteristik Fisikokimia Dan Kadar Antosianin Minuman Serbuk Kombinasi Susu Sapi Dan Ubi Jalar Ungu ( Ipomoea batatas L.) Skripsi," Universitas Hasanuddin Makasar, 2018.

[14] N. El Husna, M. Novita, and S. Rohaya, "Kandungan Antosianin dan Aktivitas Antioksidan Ubi Jalar Ungu Segar dan Produk Olahannya," 2013.

[15] C. N. Arifah, C. Saleh, and Erwin, "Uji 
Fitokimia Dan Uji Stabilitas Zat Warna dari Ekstrak Biji Buah Alpukat (Persea americana Mill) Dengan Metode Spektorskopis UVVIS," 2016.

[16] A. E. Ramadhan and H. A. Phaza, "Pengaruh Konsentrasi Etanol, Suhu dan Jumlah Stage pada Ekstraksi Oleoresin Jahe (Zingiber officinale Rosc) Secara Batch," Universitas Diponegoro, 2010.

[17] E. R. Srijanto, Bambang, Idah Rosidah and M. Gustini Syabirin, Aan, "Pengaruh Waktu, Suhu Dan Perbandingan Bahan Baku-Pelarut Pada Ekstraksi Kurkumin Dari Temulawak (Curcuma Xanthorriza Roxb.) Dengan Pelarut Aseton," in Prosiding Seminar Nasional Rekayasa Kimia dan Proses, 2004, pp. 1-5.

[18] S. Sudarmi, P. Subagyo, A. Susanti, and A. S. Wahyuningsih, "Ekstraksi Sederhana Antosianon dari Kulit Buah Naga (Hylocereus polyrhizus) sebagai Pewarna Alami," Eksergi, vol. 12, no. 1, p. 05, 2015.

[19] Fitriani and N. Awaliyah, "( the Effect of Extraction Temperature and Warming Time," Majalah Ilmiah Al Ribaath, Universitas Muhammadiyah Pontianak, vol. 12, no. 1, pp. 35-43, 2015.

[20] Molyneux P, "The use of the stable free radical diphenylpicryl-hydrazyl (DPPH) for estimating anti-oxidant activity," 2004.

[21] D. Tristanti, A. Ismawati, B. T. Pradana, and J. E. Jonathan, "Pengajuan Aktivitas Antioksidan Menggunakan Metode DPPH pada Daun Tanjung (Mimosa Elergi L). Prosiding Seminar Nasional Teknik Kimia Kejauangan," jurnal upnyk, pp. 1-7, 2016.

[22] F. Susilowati, "Uji Brine Shrimp Lethality Test (Bsit) Ekstrak Etil Asetat Spons Calthropella Sp. Asal Zona Intertidal Pantai Krakal Gunung Kidul Yogyakarta,” 2017.

[23] J., D. Osmeli, and . Y., "Kandungan Senyawa Kimia, Uji Toksisitas (Brine Shrimp Lethality Test) Dan Antioksidan (1,1-Diphenyl-2Pikrilhydrazyl) Dari Ekstrak Daun Saga (Abrus precatorius L.)," 2010. 